\title{
DETERIMINATION OF VARIOUS CLINICAL STAGES OF CHRONIC HEPATITIS B THROUGH MEASURING VIRUS LOAD DNA BY REAL-TIME POLYMERASE CHAIN REACTION (RT-PCR)
}

KEY WORDS:

$\begin{array}{ll}\text { Subhash Kumar } & \begin{array}{l}\text { Department of Biotechnology, Magadh University, Bodh Gaya, India. } \\ \text { *Corresponding Author }\end{array}\end{array}$

MD. Mohammad

Sohail

Department of Biotechnology, Magadh University, Bodh Gaya, India.

Jainendra Kumar Department of Biotechnology, Magadh University, Bodh Gaya, India.

Objective And Aim: There was a paradigm shift of hepatitis B (CHB) diagnosis as clinicians are shifted to molecular diagnostic methods from serological one. Specially in molecular system to determine response of treatment as well as different stages of infection as well as recovery by quantification of viral DNA load through real time polymerase chain reaction (RT-PCR). The main objective of the study is to determine the various clinical stages of chronic hepatitis $B$ through measuring virus load DNA by real-time polymerase chain reaction (RT-PCR)

Material And Methods: This is a retrospective study of those patients whose ALT (elevated) and HBeAg (positive) status is known. Serum fraction were initially obtained after 4 hour centrifugation of blood sample and nucleic acid was extracted at $-80^{\circ} \mathrm{C}$. Qiagen DNA extraction kit were used to extract DNA. 48-well MiniOpticon by Bio-red machine and with the help of Geno-sense HBV quantitative PCR kit, real-time polymerase chain reaction (RT-PCR) was conducted.

Result: The study was conducted in 64 patients. It has been found that among this patients inactive carriers that is ALT normal and HBeAg-negative were 27 (42.2\%) and rest of the patients had HBeAg-positive or HBeAg-negative with ALT elevated that is they were chronic active hepatitis B patients. HBeAg was negative in $42(65.6 \%)$ and positive in 22 (33.4\%) subjects. $15(23 \%)$ patients were infected with Chronic hepatitis B among the patients who were HBeAgnegative. Among 64 subjects, detectable viral load was found in $55(86 \%)$ CHB patients. A significantly lower (median 5.6 $\times 105$ ) serum HBV DNA load were found in $\mathrm{HBeAg}$-negative 16 patients as compare to 26 patients with higher viral load (median $2.5 \times 108$ ) and were HBeAg-positive. It has also found that viral load was quite higher (median $1.5 \times 103$ ) in 27 inactive carriers. Antiviral therapy was started in HBeAg-negative 6 patients and HBeAg-positive 13 patients based on the viral load.

Conclusion: Stages of CHB can be determined by Quantitation of HBV DNA based on ALT (elevated or not) and HBeAg (positive or negative) status. For those patients who are inactive carriers and HBeAg-negative with respect to viral load it could play an important role in assessment and to decide on antiviral therapy.

INTRODUCTION:

Hepatitis B infection is still a leading global health problem. It has already been estimated by WHO (World Health Organization) that worldwide infected with Hepatitis B virus were more than 2 billion and approximately 240 million individuals mainly from liver cirrhosis and hepatocellular carcinoma (HCC) at risk of serious illness and death and have chronic (long-term) liver infections [1-5]. In a study conducted by Tandon BN et al is had estimated that around $4 \%$ estimated carrier rate among pool of approximately 36 southern Indian patients [6]. In different parts of the country differences in HBV carrier rates reported in previous studies and mainly due to variations in economic, social, and health factors in different regions of India [7-13]. Liver damage of caring degree generally found to be different in each clinical stages which once again emphasis the factor that to manage CHB infection asessomint these clinical stages is essential.

Hepatocellular carcinoma (HCC), cirrhosis AND inactive carrier state to chronic hepatitis are the major ranges of chronic infection that are found clinically [14]. Chronic hepatitis B (CHB) infection are progress to $80-90 \%$ of infants, $10-25 \%$ of young children and Less than $5 \%$ of adults [15].

There was a paradigm shift of hepatitis B (CHB) diagnosis as clinicians are shifted to molecular diagnostic methods from serological one. Specially in molecular system to determine response of treatment as well as different stages of infection as well as recovery by quantification of viral DNA load through real time polymerase chain reaction (RT-PCR). In current time the treatment session generally taken based on the clinical status of the patient, $\mathrm{HBeAg}$ status, ALT levels, serum HBV DNA and and liver histology [16].

The main objective of the study is to determine the various twww.worldwidejournals.com clinical stages of chronic hepatitis B through measuring virus load DNA by real-time polymerase chain reaction (RT-PCR).

\section{MATERIAL AND IMETHODS:}

This is a retrospective study of those patients whose ALT (elevated) and $\mathrm{HBeAg}$ (positive) status is known. CHB patients in whom longer than six months HBsAg value was positive were included in this study. Major three study group which was included in this retrospective study was normal ALT with $\mathrm{HBeAg}$-negative, elevated ALT with $\mathrm{HBeAg}$-negative and elevated ALT with HBeAg-positive. Patients were excluded from the study if they were found to co-infected with hepatitis $\mathrm{C}$ and HIV Or on treatment and pregnant or lactating women.

For HBV DNA quantitation 3-5 $\mathrm{ml}$ blood sample were collected from each patients. Serum fraction were initially obtained after 4 hour centrifugation of blood sample and nucleic acid was extracted at $-80^{\circ} \mathrm{C}$. Qiagen DNA extraction kit were used to extract DNA. 48-well MiniOpticon by Bio-red machine and with the help of Geno-sense HBV quantitative PCR kit, real-time polymerase chain reaction (RT-PCR) was conducted. Viral load was expressed in $\mathrm{IU} / \mathrm{ml}(1 \mathrm{IU} / \mathrm{ml}=5.6$ copies/ml) sing the external positive controls in quantification machine.

Statistical software SPSS ver 13.0 (SPSS Inc., Chicago, IL, USA) were used to calculate statistical measurements. Values were considered statistically significant when $\mathrm{p}$ value $<0.05$.

\section{RESULT:}

The study was conducted in 64 patients. Demographic details including subjects age (years), gender (male or female), HbsAg, AbeAg, ALT (IU/L) levels, DNA load number and HBV DNA levels were illustrated in table 1. 


Table 1: Characteristics Of CHB Patients
\begin{tabular}{|l|l|l|l|}
\hline $\begin{array}{l}\text { Characteristi } \\
\text { cs }\end{array}$ & $\begin{array}{l}\text { HBeAg } \\
\text { Positive } \\
(\mathbf{N}=\mathbf{2 2})\end{array}$ & $\begin{array}{l}\text { HBeAg } \\
\text { Negative } \\
(\mathbf{N}=15)\end{array}$ & $\begin{array}{l}\text { Inactive } \\
\text { carriers } \\
\text { (N=27) }\end{array}$ \\
\hline Age (years) & $36.25 \pm 13.86$ & $37.41 \pm 12.26$ & $41.43 \pm 12.79$ \\
\hline $\begin{array}{l}\text { Gender } \\
\text { (male/female) } \\
(\%)\end{array}$ & $\begin{array}{l}13(59 \%) / \\
09(41 \%)\end{array}$ & $\begin{array}{l}12(80 \%) / \\
03(20 \%)\end{array}$ & $\begin{array}{l}15(56 \%) / \\
12(44 \%)\end{array}$ \\
\hline HBsAg & Positive & Positive & Positive \\
\hline HBeAg & Positive & Negative & Negative \\
\hline ALT (IU/L) & Elevated & Elevated & Normal \\
\hline $\begin{array}{l}\text { DNA Load } \\
\text { (N\%) }\end{array}$ & $22(100 \%)$ & $15(100 \%)$ & $18(66.7 \%)$ \\
\hline DNA Load & $\begin{array}{l}2.5 \times 10^{8 \pm} \\
2.2 \times 10^{5}\end{array}$ & $\begin{array}{l}5.6 \times 10^{5 \pm 1.4} \times \\
10^{5}\end{array}$ & $\begin{array}{l}1.5 \times 10^{3 \pm 1.7} \\
10^{2}\end{array}$ \\
\hline
\end{tabular}

It has been found that among this patients inactive carriers that is ALT normal and HBeAg-negative were 27 (42.2\%) and rest of the patients had $\mathrm{HBeAg}$-positive or $\mathrm{HBeAg}$-negative with ALT elevated that is they were chronic active hepatitis B patients. $\mathrm{HBeAg}$ was negative in $42(65.6 \%)$ and positive in 22 $(33.4 \%)$ subjects. $15(23 \%)$ patients were infected with Chronic hepatitis B among the patients who were HBeAgnegative. Among 64 subjects, detectable viral load was found in $55(86 \%)$ CHB patients.

A significantly lower (median $5.6 \times 10^{5}$ ) serum HBV DNA load were found in $\mathrm{HBeAg}$-negativel 6 patients as compare to 26 patients with higher viral load (median $2.5 \times 10^{8}$ ) and were were $\mathrm{HBeAg}$-positive. It has also found that viral load was quite higher (median $1.5 \times 10^{3}$ ) in 27 inactive carriers. Antiviral therapy was started in HBeAg-negative 6 patients and $\mathrm{HBeAg}$-positive 13 patients based on the viral load.

\section{DISCUSSION}

The main aim of the study is to determine the various clinical stages of chronic hepatitis B through measuring virus load DNA by real-time polymerase chain reaction (RT-PCR). This study has revealed that among participant $\mathrm{HBeAg}$ was negative in $42(65.6 \%)$ and positive in $22(33.4 \%)$ subjects. 15 $(23 \%)$ patients were infected with Chronic hepatitis B among the patients who were $\mathrm{HBeAg}$-negative. There are a quite few studies which confirmed that $83-100 \%$ of $\mathrm{HBeAg}$-positive patients have the presence of HBV DNA $[17,18]$. Studies had already confirmed that, as compare to HBeAg-negative group HBV DNA levels were significantly higher in HBeAg-positive group [19-21]. In the present study, during immune clearance of a wild-type strain $\mathrm{HBeAg}$-negative strain emerges with the highest load was $1.5 \times 103$ as compare to HbeAg-negative chronic hepatitis patients with low of $2.5 \times 108$. And it also reveals that $\mathrm{HBeAg}$-negative mutant selection occurred when on the wild-type strain immune pressure increased. During treatment it may occur spontaneously [22].

\section{CONCLUSION:}

Stages of CHB can be determined by Quantitation of HBV DNA based on ALT (elevated or not) and HBeAg (positive or negative) status. For those patients who are inactive carriers and $\mathrm{HBeAg}$-negative with respect to viral load it could play an important role in assessment and to decide on antiviral therapy.

\section{REFERENCES:}

1. World Health Organization. Hepatitis B.World Health Organization Fact Sheet No 204. Available at:http://www.who.int/mediacentre/factsheets/fs204/en/.

2. Lavanchy D. Hepatitis B virus epidemiology, disease burden, treatment, and current and emerging prevention and control measures. J Viral Hepat. 2004;11:97-107.

3. Lok A.S. Chronic hepatitis B. NEnglJMed 2002;346:1682-1683.

4. Goldstein S.T., Zhou F., Hadler S.C., Bell B.P., Mast E.E., Margolis H.S. A mathematical model to estimate global hepatitis B disease burden and vaccination impact.Int JEpidemiol.2005;34:1329-1339.

5. Te H.S., Jensen D.M. Epidemiology of hepatitis B and C viruses: a global overview. Clin Liver Dis. 2010;14:1-21.

6. Tandan BN, Acharya SK, Tandon A. Epidemiology of hepatitis B virus infection in India. Gut 1996;38(suppl2):S56-S59.
7. Irshad M, Joshi YK, Acharya SK, Tandon BN. Prevalence of hepatitis B virus infection in healthy persons in North India. Natl Med j India 1994;7:210-2.

8. Singhvi A, Putimood RB, John TJ, etal. The prevalence of markers for hepatitis $B$ and human immunodeficiency viruses, malarial parasites, and micro flora in blood donors in a large hospital in South India. J Trop Med Hyg 1990; 93: 178-82.

9. Prasad SR, Rodrigues FM, Dhonje SP, Ramamoorthy CL. Prevalence and sub types of hepatitis B surface antigen in the tribal population inArunachal Pradesh.Ind JMedRes (A) 1983;78:300-6

10. Joshi SH, Gorakshakar AC, Mukerjee M, et al. Prevalence ofHBsAg carriersamong some tribesofMadhya Pradesh. Ind JtMed Res (A) 1990; 91: 341-3.

11. Dutta S. An overview of molecular epidemiology of hepatitis B virus (HBV) in India.Virol J.2008;5:156.

12. Abraham P.Viral hepatitis in India. Clin Lab Med.2012;32:159-174

13. Thyagarajan S.P., Jayaram S., Mohanavalli B. Prevalence of HBV in general population of India. In: Sarin S.K., Singal A.K., editors. Hepatitis B in India: Problems and Prevention. CBS Publishers and Distributors; New Delhi: 1996. pp.5-16.

14. Madan K, Batra Y, Jha JK, Kumar S, Kalra N, Paul SB, Clinical relevance of HBV DNA load in patients with chronic hepatitis B infection. Trop Gastroenterol 2008;29:84-90.

15. Kessler HH, Preininger S, Stelzl E, Daghofer E, Santner BI, Marth E, et al. Identification of different states of hepatitis $B$ virus infection with a quantitative PCR assay. Clin Diagn Lab Immunol 2000; 7:298-300.

16. Dienes HP, Gerken G, Goeagen B, Heermann K, Gerlich W, Meyer Zum Buschenfelde KH. Analysis of precore DNA sequence and detection of precore antigen in liver specimens from patients with anti-hepatitis B epositive chronic hepatitis. Hepatology 1995;21:1-7.

17. Loriot MA, Marcellin P, Bismuth E, Martinot-Peignoux M, Boyer N, Degott C, et al. Demonstration of hepatitis B virus DNA by polymerase chain reaction in the serum and the liver after spontaneous or therapeutically induced $\mathrm{HBeAg}$ to anti-HBe or $\mathrm{HBsAg}$ to anti-HBs seroconversion in patients with chronic hepatitis B. Hepatology 1992;15:32-6.

18. Xie Y, Zhao H, Da WS, Xu DZ. HBV DNA level and antigen concentration in evaluating liver damage of patients with chronic hepatitis B. Hepatobiliary Pancreat Dis Int 2003;2:418-22.

19. Kessler HH, Preininger S, Stelzl E, Daghofer E, Santner BI, Marth E, et al. Identification of different states of hepatitis B virus infection with a quantitative PCR assay. Clin Diagn Lab Immunol 2000; 7:298-300.

20. Heo J, Baik TH, Kim HH, Kim GH, Kang DH, Song GA, et al. Serum hepatitis B virus (HBV) DNA levels at different stages of clinical course in patients with chronic HBV infection in an endemic area.J Korean Med Sc 2003;18:686-90.

21. Changotra H, Dwived A, Nayyar AK, Sehajpal PK. Diagnosing different stages of hepatitis B infection using a competitive polymerase chain reaction assay. Indian J Med Microbiol 2008;26:138-42.

22. Iloeje UH, Yang HI, Su J, Jen CL, You SL, Chen CJ; Risk Evaluation of Viral Load Elevation and Associated Liver Disease/Cancer-In HBV (the REVEAL-HBV) Study Group. Predicting cirrhosis risk based on the level of circulating hepatitis B viral load. Gastroenterology 2006;130:678-86. 